UDC 37.02; 37.016: $008+01$

DOI: $10.23951 / 2782-2575-2021-1-87-103$

\title{
I.S. TURGENEV IN A MODERN SCHOOL*
}

\section{V.A. Domansky}

\section{St. Petersburg Institute of Business and Innovation, St. Petersburg, Russian Federation}

Introduction. The article's relevance is determined by the need to find new ways to study Russian classics in a modern school setting. As studies show, students' quality of classics perception decreases every year, explained by socio-cultural conditions and methodological aspects. This problem requires special attention in connection with the past and upcoming 200th anniversaries of the most significant canonical writers: I.A. Goncharov, M.Yu. Lermontov, I.S. Turgenev, A.A. Fet, N.A. Nekrasov, A.N. Ostrovsky, F.M. Dostoevsky, L.N. Tolstoy. The author believes that literary anniversaries are a good incentive to revive the most influential classical literature and include students in their country's cultural life. And the literature teacher might benefit from knowing the anniversaries mentioned above and whether there are any events dedicated to these anniversaries. Teachers should also contribute to a philological environment in the school and continuously improve literary and methodological competence.

The study is based on the biography and works by Turgenev, whose 200th anniversary was widely celebrated in 2018 . We want to share the experience of teaching the creative heritage of an outstanding Russian writer in a modern school; we identified the difficulties that literature teachers face and outlined productive ways to overcome psychological and pedagogical contradictions in the theory and practice of literary education, which happens primarily due to the gap between the scientific and pedagogical studies of Turgenev's works.

Materials and methods. The study hypothetically formulated the problem, which was confirmed during the analysis of scientific and methodological works and while evaluating students' residual knowledge.

Results and discussion. Stereotypes of students' perception of the writer's personality and his creative work are revealed. Productive ways and forms of acquaintance with the author's personality, new genres of creating a biographical sketch are considered. Particular attention is paid to Turgenev's concept of nature and love, their aesthetic and philosophical essence. New methods of enhancing the reading activity are proposed, particularly methods to create intertextuality (based on the appeal to the landscapes by the artists from the Barbizon school). The ways of acquainting students with the writer's manor texts in the context of the Russian manor culture are presented. Specific recommendations are given to include the "Home of the Gentry" novel in the 10th-grade literature class. New approaches to the study of the "Fathers and Sons" novel are revealed, the comparison teaching method of the television series based on the writer's work "Bazarov's Mistake" by Avdotya Smirnova is proposed.

Conclusion. To actualize the students' perception of Turgenev's novel, a model of a lesson dialogue is developed with the involvement of works of modern Literature (Vera Tchaikovskaya's remake "New under the Sun"). In general, the study showed that it is possible to teach further methodological improvement of Turgenev's creative work at school by relying on established traditions and using new forms and methods of the reading activity organization, and by increasing the philological competence of the literature teacher.

Keywords: updating the Russian classical Literature, I.S. Turgenev in the modern school, traditions and innovation, stereotypes of the writer's world perception, knowledge

* Original Russian language version of the article: Domanskiy V.A. I.S. Turgenev v shkole: traditsii i preodolenie stereotipov [I.S. Turgenev in School: Traditions and Overcoming Stereotypes]. Vestnik Tomskogo gosudarstvennogo pedagogicheskogo universiteta - TSPU Bulletin, 2019, vol. 1 (198), pp. 113-127. DOI: 10.23951/1609-624X-2019-1-113-127 
evaluation, Turgenev's concept of nature and love, manor texts, methods of reading activity enhancement, methods to create intertextuality, intermodality in a literature class.

\section{Introduction}

In 2018 Russia and Europe widely celebrated the 200th anniversary of I.S. Turgenev, as evidenced by numerous international conferences ${ }^{1}$, new books, and monographs publications dedicated to his life and works ${ }^{2}$. In Moscow, on Ostozhenka, for Turgenev's anniversary, the reconstruction of the Turgenev Museum was completed, and the opening of the monument to the writer took place. The Turgenev theme was one of the central in the VII St. Petersburg International Cultural Forum program, which took place on November 15-17.

All these events speak of the growing attention of philologists and the public to the personality and creative heritage of the great Russian writer. At the same time, Turgenev has not yet been assigned the place in the world literature and culture that he deserves on a par with our other canonical writers - Tolstoy, Dostoevsky, Chekhov. This very idea was often voiced in many reports among the participants of the conferences on Turgenev.

The underestimation of Turgenev as a writer is explained by stereotypes of his creative work perception, which began to take shape in the public mind after the publication of his most famous novel, "Fathers and Sons," 1862. The controversy around the book crossed all the lines, criticism without objectivity turning into satire, parody, caricature. In this regard, the most exemplary is the polemical article by M.A. Antonovich, "Asmodeus of Our Time," published in "The Contemporary." To convince his reader that the author of the novel has created a caustic satire on the younger generation, the critic uses various parody techniques to create a comic effect. This is, above all, a primitive retelling of the novel, in which all artistry disappears; the initial idea of the article is that "the new work of Mr. Turgenev is extremely unsatisfactory in artistic terms" [1, p. 36]. Antonovich was echoed by D. Minaev and V. Kurochkin, who mocked the characters of Turgenev's novel and its author [2, p. 108-111].

In the context of the late 1860s-1870s, Turgenev's late novels were also deceitfully criticized, not to mention his "Mysterious Stories." Turgenev was not lucky either during the formation and development of Russian modernism when new forms in literature were in demand. "The singer for noble nests" was thrown "from the ship of modernity" as an archaic writer, whose time was irrevocably gone. Even the New Peasant poet N. Klyuev spoke quite ironically in one of his poems about the author of manor novels:

"Let Turgenev grieve about the manor on the shelf, languishing slowly with a paper tear" [3, p. 400].

But most of all, in the era of the Silver Age, Turgenev's literary reputation was harmed by Yu.I. Eichenwald spoke of him not as a classic of Russian Literature but as a second-tier writer:

\footnotetext{
1 "Turgenev and the Liberal Idea in Russia" (April 19-21, Perm State Humanitarian Pedagogical University); "Turgenev Days in Brussels: Russian Writers Abroad" (4-8 July, Turgenev Society of the Benelux, Russian Center for Science and Culture in Brussels); "I.S. Turgenev and World Literature" (October 1-19, IMLI RAN, Moscow); "Turgenev and the Russian World" (October 29-31, IRLI RAS, St. Petersburg); "I.S. Turgenev and World Literature" (October 24-25, Oryol State University named after I. Turgenev); Colloque International "Ivan Tourguéniev, hommedepaix" (November 7-10, International colloquium "Ivan Turgenev - a man of the world." Under the patronage of UNESCO, Paris Bougival); International scientific and practical conference dedicated to the 200th anniversary (November 15-17, St. Petersburg State University); "I.S. Turgenev is our contemporary" (19-20 November, The Pushkin State Museum, Library-reading room named after I.S. Turgenev); "Turgenev in cross-cultural communication" (November 21-22, Russian State University for the Humanities).

${ }^{2}$ Golovko V.M. Philosophical, worldview and creative searches of I.S. Turgenev in the context of culture. Stavropol: publishing house of NCFU, 2017; Golovko V.M. I.S. Turgenev: the art of artistic philosophizing. Moscow: Flinta, 2018; Belyaeva I.A. Works by I.S. Turgenev: Faustian contexts. Moscow: Nestor-History, 2018; Domansky V.A., Kafanova O.B. The artistic worlds of Ivan Turgenev. Moscow: Flinta, 2018; Rebel G.M. Turgenev in Russian culture. Moscow; St. Petersburg: Nestor-History, 2018; Tchaikovskaya V.M. Such a versatile Turgenev. On the occasion of the 200th anniversary of his birth. Moscow: Academic project, 2018; I. S. Turgenev. Moscow time. Author-comp. N. A. Kargapolova. Moscow: Historical Museum, 2018.
} 
"Turgenev is not deep. And in many ways, his creative work is commonplace $<\ldots>$ some plots and themes are sinful to subject to watercolor treatment. Meanwhile, he talks about everything, he talks of death, horror, and madness, but all this is done superficially and in tones that are too light. In general, he has an easy attitude to life, and it is almost insulting to see how difficult problems of the spirit fit into his little stories, just like in some boxes" [4, p. four].

Everything changed during the Soviet period. Thanks to his "Fathers and Sons," Turgenev became one of the most recognized Russian classics, although his work was viewed quite straightforwardly as a kind of artistic illustration of Russia's revolutionary democratic movement stages.

"Fathers and Sons" became a textbook in school curricula, which was interpreted very ideologically. The "Sons" (revolutionary democrats) were recognized as positive characters since the future was after them. Negative, or almost negative, were the "Fathers" (noble liberals) who had outlived their days. Bazarov was called almost the first image of a Russian revolutionary, although he was overshadowed by the more understandable and straightforward characters by N.G. Chernyshevsky "What is to be done?" [5-8].

Turgenev's "Fathers and Sons" was filmed, and in the first feature film, in 1958, directed by Natalia Rashevskaya and Adolf Bergunker, the outstanding ensemble of actors managed to convey the social and psychological drama of the characters. The leading actor - Viktor Avdyushko - created an attractive image of a strong and courageous Bazarov, who was liked by millions of viewers. The film's success made Turgenev's novel famous, and people began to read and study it more willingly.

In the 1970s, with the advent of A.I. Batuto [9], N.N. Mostovskaya [10], A.B. Muratov [11], V.G. Odinokov [12], S.E. Shatalov [13], and others, finally, a scientific "breakthrough" in Turgenev studies began. A wide range of philosophical, socio-psychological, and cultural problems in Turgenev's works, with access to the new contexts, was investigated in the writings of 1980-2000. N.P. Generalova [14], V.M. Golovko [15], G.B. Kurlyandskaya [16], Yu.V. Lebedev [17], V.M. Markovich [18], V.A. Nedzvetskiy [19], G.A. Time [20] and others).

The basis for a qualitatively new level of the writer's heritage perception is the publication of the complete Turgenev's collection in 30 volumes. (started under the editorship of M.P. Alekseev and continued under the editorship of N.P. Generalova) The publication of new Turgenev texts was accompanied by series of articles and comments to each volume. This collection should become a kind of matrix in the works of Turgenev scholars and teachers of literature and philology students.

\section{Materials and Methods}

In the Russian school, after overcoming the sociological approach to the study of literature, which lasted from the 1930s till the 1950s, interest in Turgenev's personality increased. This was largely facilitated by the appearance of a textbook for high school students by N.N. Naumova [21], which went through several editions. But by the year 2000, it turned out to be forgotten entirely: by that time, not only the content of the school literary education had radically changed, but also the didactics of the lesson itself.

A good help for the teacher in the 1980s was the "Turgenev at school" textbook, compiled by T.F. Kurdyumova [22], a well-known methodology scientist, editor of literature programs, and author of textbooks for secondary schools. It presents methodological approaches and lesson plans to study the writer's works from the 5 th till the 10 th grades. This textbook, by tradition, is still one of the leading books in the methodological library of the literature teacher, along with the "Turgenev and Russian Literature" textbook by the famous Turgenev researcher G.B. Kurlyandskaya. The book presents a broad literary context of the writer's works [23]. 
Since the 1990s, language specialists also use the book by Yu.V Lebedev, in which the biography of the writer is vividly and thoroughly presented [24].

Unfortunately, in the 2000s and 2010s, no serious publications appeared in the pedagogical Turgenev study, although the school has always been a sensitive barometer, reacting to all changes in the public consciousness. A brief review of the methodological literature shows the need for new textbooks to help the literature teacher with lectures on the study of Turgenev's creative work, especially biographical lectures.

In the theory and practice of literature teaching, there are several ways to study the writer's biography, depending on the students' age. In grades 5 and 6, brief biographical information about the writer is given; in grades 7 and 8, the writer's life is partially introduced into the historical context and presented in the genre of a short biographical sketch. And finally, in high school, when studying an author, it is proposed to research biography in conjunction with the literary works, including a historical approach to the study of literary phenomena [25].

Even though these biography study methods have been tested by long-term school practice, their productivity can only be talked about with the successful development of the content component of biographical lessons and teaching materials that correspond to the student's agespecific psychological characteristics.

We made residual knowledge assessments on Turgenev's biography in the Vsevolozhsky and Vyborgsky districts of the Leningrad region for several years. For the evaluation, middle school students wrote a short essay about the writer and his life during a lesson. In addition to the pieces, teachers also considered students' oral statements. Based on these essays and the schoolchildren's answers, a generalized text was built: "Turgenev is a great Russian writer who was born in the depths of Russia, in the family of a wealthy landowner. Since childhood, he was friends with peasant children, whom he later wrote about in the story "Bezhin Meadow." He was very fond of hunting but even more fond of Russian nature. He traveled half of Russia with a hunting shotgun and recounted his meetings with different people in the book "A Sportsman $>$ Sketches." Turgenev was close to the Russian people, knew their customs well, as evidenced by his short story "Mumu." In this story, he portrayed a simple peasant, the dumb "Bogatyr" Gerasim, who was disliked by an evil landowner who looked like the writer's mother. Turgenev often traveled abroad, where he met a singer; he fell in love with her very much but did not marry her. He wrote many books about children and adults, one of them he even called "Fathers and sons." I like his works and characters, especially his Biryuk - a real Russian man, strong and fair."

As you can see, the adolescents' judgments about the writer and his life are naive, sincere. Due to the peculiarities of age and due to the lack of knowledge about the essential facts of the writer's biography, it is difficult for students to compose a complete, holistic story; therefore, schoolchildren create their own conditional, even slightly mythologized story of Turgenev's life, which is then hard to change. Of course, when teaching literature, a lot depends on the teacher, his or her education, culture, pedagogical skills, but also the textbook, which students use to prepare for lessons, plays an important role. The method of expert assessments, which was used in the experiment among teachers in the Leningrad region (we interviewed approximately 100 teachers of Russian language and literature), showed that the genre of "curriculum vitae" used in the literature textbooks for middle grades is ineffective. The teachers suggested that it would be more productive to put information about the main dates of the writer's life in a literature textbook, and the acquaintance with his personality is best made with the help of a fictionalized story about the author. Of course, we can apply this to all writers, not just Turgenev.

The thoughts of high school students about the personality of Turgenev are more diverse than the middle school ones. In many ways, they are motivated by the monographic study of the 
writer's creative work and the acquaintance with other different sources. We obtained the study material during the school Olympiads. Students were asked to draw up Turgenev's short biographical outline, name the people and circumstances that played a significant role in forming his personality, find the moments of the writer's life that made a memorable impression on them. Another task was related to the compilation of the writer's psychological portrait. The experiment was also carried out in schools of the Leningrad region during the second term of the academic year, and it covered more than 120 10th grade students. The material obtained testifies to the insufficient knowledge of Turgenev's biography: more than half of the students in the experiment did not cope with the task. Particular difficulties arose in building a psychological portrait of the writer, isolating and analyzing the most important facts of his biography. The shallow knowledge of Turgenev's biography and the inability to motivate its attributes, as the experiment showed, lies not only in the quality of teaching but also in the information that students receive from educational literature and in the form of its presentation.

Let us turn to specific examples of Turgenev's life in some literature textbooks for the 10th grade. Thus, in one of them, written under the guidance of Professor I.N. Sukhikh ${ }^{1}$ (2011), the author of the biographical sketch presented Turgenev's biography in a fun and entertaining way, believing that he could remove the prevailing stereotypes about the writer. But the story about the author in the biographical article sometimes turns into the author's game with a young reader, and a fictionalized story replaces a scientific biography.

Let's turn to a specific example illustrating the interpretation of the facts of Turgenev's biography in this textbook:

"The handsome, twenty-two-year-old Sergei Nikolaevich Turgenev was a noble, but a very poor noble. Varvara Petrovna Lutovinova -6 years older, not good-looking, not very educated, but she had 5 thousand serfs, 600 thousand rubles, and several estates inherited from her uncle. $<\ldots>$ Even after becoming a family, the parents lived separate lives. The father did not introduce his wife to his circle, had love affairs on the side, looked indifferently at what was happening in his house, including the upbringing of his sons. He died in 1834, at the age of 43, turning into such a convenient poetic memory for Varvara Petrovna" [26, part 2, p. 5-6].

Reading this fragment of the textbook, one involuntarily asks: do students need these details from the life of the writer's parents and presented in such a playful form to understand the personality of the writer? In addition, I would like to argue with some of the statements. Varvara Petrovna can hardly be called "not very educated." She knew French well, read a lot, studied botany, was very receptive to acquiring new knowledge. Her recently published letters to Ivan allow us to see the personality of the writer's mother from a new perspective, who sought to cultivate will, responsibility, and hard work in her son, wanted to be not only his mentor but also the first reader and critic of his works, even a friend [27].

Turgenev's father, too, should not be spoken of in such a tone. He was a good educator, as evidenced by his surviving letters to his sons. And the story of his love for Princess Yekaterina Lvovna Shakhovskaya is the key to understanding Turgenev's "First Love Story," which reveals the tragic essence of love in the writer's works.

Another approach to writing Turgenev's biography was carried out on the pages of a literature textbook, edited by I.G. Marantzman [28]. The authors tried to present the writer's life in connection with the stages of his creative work and the most critical events in the historical and cultural life of Russia and Europe. The writer's personality is presented on a large scale by attracting reviews of contemporaries about the writer, his letters, conceptual presentation of

\footnotetext{
${ }^{1}$ The textbook is included in the federal list of textbooks for the 2018-2019 academic year (basic level).
} 
the material, although without any everyday life details. Some chapters of the biographical sketch are called interesting and problematic: "No one could have done it better than you..." (reviews of French writers about "A Sportsman>s Sketches"), "I spent the best years of my life here" (about Turgenev's stay in Spasskoye-Lutovinovo), "Tragic Music of Love" (love in Turgenev's life and creative work). The authors of the textbook also use productive techniques for organizing students' independent work related to the study of the writer's biography: using slides and documentary materials to create the content of an extramural excursion to Spasskoye, study Turgenev's iconography, selectively read letters from which students learn about the relationship between Turgenev and Belinsky, Herzen, Pauline Viardot.

At the same time, the perspective given by the authors for considering Turgenev's biography at the end of the essay leads to the fact that it is primarily dissolved in his creative activity. Personality is replaced by a story about the writer's works, and gradually, while reading the textbook, interest in the writer's biography fades away. Of course, the volume restrictions of the textbook did not allow its authors, who kept on studying Turgenev's works, to turn to other facts and episodes of his life. And this is a general contradiction with which, according to Yu.M. Lotman, every time the writer's biography author comes across: "Blending the author's biography and the analysis of his or her works rarely leads to success. Of course, the life of a creative person is inseparable from his or her works, but the biography describes the creative work from a different angle than a monograph" [29, p. 228].

Next is the fictionalized story about Turgenev's life by B. Zaitsev "The Life of Turgenev" [30]. The author does not always follow the records and documents about Turgenev but gives descriptions, portraits, dialogues, and mise-en-scènes a beautiful, rich personality of the writer appears before the reader. This book can be successfully recommended for out-of-class reading and help to "revive" Turgenev's character and avoid schematism. But in a fictionalized biography, personality still dominates creativity, pushing it into the background, and this is not always acceptable for educational literature.

Another way of presenting Turgenev's biography was proposed by the well-known literary critic Yu.V. Lebedev. According to the classification of Yu.M. Lotman, his book is a biographical monograph of a scientific type [17]. Turgenev's life is presented holistically, in numerous details and nuances, and in close connection with his creative work. The author seeks to combine documentary with artistry and scientific conceptuality synthetically. But surveys of students show that they have difficulty reading the book. Overloading it with factual material leads to the fact that students either lose interest or perceive it fragmentarily. In addition, it is also necessary to take into account the large volume of the book, for which the tenth graders simply do not have time to read. Thus, another format is suggested: a biography text adapted to the students' perception.

In the study (using the expert assessments method), a biographical article in a textbook, edited by B.A. Lanin ${ }^{1}$ [31], was considered. The expert teachers concluded that this article is a collection of facts behind which it is difficult to discern the writer's unique personality.

The experiment carried out and the analysis of biographical articles in textbooks on literature for the 10th grade lead to the idea that it is necessary to look for new ways and forms of writing a biographical sketch or biographical article. It is not so much everyday life details that are important, but showing the process of formation and development of the writer's personality, a person of the 1840s in relationships and dialogues with contemporaries, Westerners and Slavophiles, liberals and democrats. A special place in the writer's biography is occupied

${ }^{1}$ The textbook is included in the federal list of textbooks for the 2018-2019 academic year (basic and advanced levels). 
by affection and music, his service to the national culture, his civic position, which manifests itself with his homeland, Russia, and social progress. In such an essay, the writer's personal and creative dominants should play a unifying role. In general, such an introduction to the study of Turgenev's personality and creativity becomes only a matrix for the subsequent independent work of students: the direction of their reading, essays, reports, creative works. The writer's biography is revealed only in the reader's interaction with his personality, the reader's ability to empathy, and the ability to interpret individual facts and consider them in the system.

The study of Turgenev's works and immersion in his artistic world begins in the 5th grade. The school has developed a stable tradition of thematic and genre study of his works: in the 5th-6th grades, the stories "Mumu" and "Bezhin Meadow" are studied in the 8th grade - the story "Asya," in the 10th - the novel "Fathers and Sons" and one of the novels ("Rudin" or "Noble's Nest").

In terms of content, such a system has justified itself and does not require radical changes. At the same time, already in middle school, the problem-thematic approach to the study of Turgenev's creative work requires some adjustments. The methodological system of lessons should be based on modern scientific achievements in the field of Turgenev studies. Thus, traditionally, in the classes on the analysis of the "Bezhin Meadow" story, the primary attention was paid to the images of peasant children and their "horror" stories. Turgenev's landscapes and literary skills were left without any attention. But it is from this story, young readers begin to comprehend the Turgenev world of nature, which like no other writer, he celebrated in the subtlest nuances and changes. The reader sees nature's images with its details and observes how lighting and colors change, can hear sounds, and feel the scents. Everything breathes, moves, lives, unfolds in time and space; one picture replaces the another. His landscapes accompany, as if fringing, the action chronotope, convey the life of the characters' souls in its fluidity and changes, reveal the beauty of the world in the moments of existence. Some of his landscapes sound like poetry in prose, as a poem about a lyrical character who discovers and comprehends the natural world and the world of his or her soul.

The formation of Turgenev as a skilled landscape painter happened already at the time of the creation of the "A Sportsman's Sketches" book, in which he demonstrates his unique vision of nature in colors, lights, tones, and shades. But the most important thing is that the writer, for the first time in Russian Literature, began to depict an ordinary realistic landscape devoid of any romantic exoticism. Here he followed in the footsteps of some of his predecessors in literature (for example, George Sand) and the Barbizon artists who depicted common nature in the vicinity of the village of Barbizon.

Therefore, in a literature class, where we turn to Turgenev's landscapes, we teach schoolchildren to discover the beauty of their native nature in paints, colors, details, and poetic images. And this must be done already during the first acquaintance with the "Bezhin Meadow" story, using photographs of Barbizon artists' paintings as a visual aid, revealing the intermedial essence of the writer's skills.

The author of "A Sportsman's Sketches," like the artists of the Barbizon school, poeticized in prose the most common natural loci of central Russia: groves, copses, meadows, swamps, ravines, glades; he described their changing colors during different times of the day, seasons, variations of lighting, and natural phenomena. And they became the personification of the homeland, Russia, and Russian nature. There is so much light in Turgenev's literary landscapes: colors with different shades, tints of light, and shadow. And this can already be demonstrated to students by referring to the first "Bezhina Meadows" landscape, a description of a beautiful July day:

"From the very early morning, the sky is clear; the morning dawn does not glow with fire: it spreads with a gentle blush. The sun - not fiery, not incandescent, as during a sultry drought, not 
dull-purple, as before a storm, but bright and welcomingly radiant - peacefully rises under a narrow and long cloud, shines freshly, and plunges into its purple fog. The upper, thin edge of the stretched cloud will sparkle with snakes; their shine is similar to the shine of forged silver..." [32, v. 4, p. 84].

There are no harsh colors in Turgenev's description: gentle and caressing tones prevail. The writer skillfully uses epithets that directly convey a certain color: lilac, white, scarlet, pink. The landscape is drawn as if the narrator constantly gazes into the distance and the sky above his head. The author of the story, as a landscape painter, managed to convey the early morning with the help of freshness and purity of colors and thoughtful spatial construction. He convinces his readers that he captured the landscape as it was on this beautiful day in July. In describing the morning, we have a broad panoramic view, the subtlest changes in the state of nature, light, and air. The early morning painting is filled with colors of different shades; the morning is described as if the artist's brush moves quickly and confidently across the canvas. The peaceful July morning is palpable and visible; its serenity is conveyed with the help of an important detail - the image of the "welcoming and radiant" sun. This description of the early morning in the story "Bezhin Meadow" can be compared with the painting by French artist C. Corot "Morning" (1865, State Hermitage).

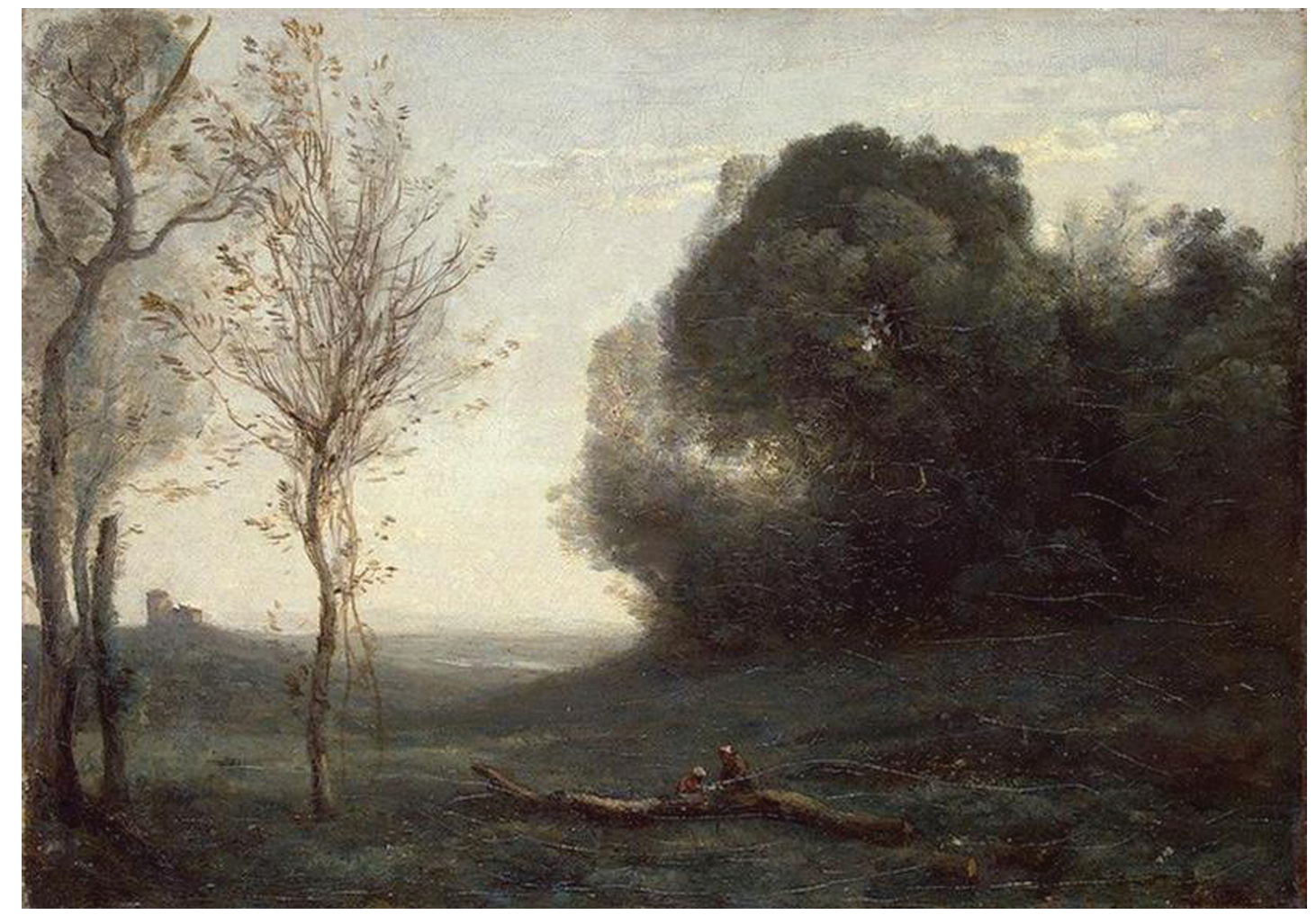

Corot and Turgenev have a tangible similarity of colors; the choice of the time of day, light golden rays of the sun, which cut through the transparent purple fog, are almost equally depicted. The clouds are airy and light; the area is filled with air, the light is very clear.

For both Corot and Turgenev, color and light become the main "characters" of the landscape. Turgenev reflects softness, the vagueness of forms, nebula covering the distance contribute to the unification of all parts of the picture. Corot's landscape is covered with the most delicate veil, along which separate bright specks of golden sun rays are scattered. But if Camille Corot, on his canvas, depicts early morning, Turgenev in an expanded landscape consistently describes 
morning, day, and evening, observing nature from the morning dawn till the last reflection of the sunset.

To activate the reading activity of schoolchildren in the process of their acquaintance with the story of "Bezhin Meadow," we can offer a system of questions and tasks:

1. Find descriptions of nature in Turgenev's story that depict morning, afternoon, evening, and night landscapes. Learn to read them dramatically. Draw one or more of these landscapes the way you see them.

2. Observe, while reading Turgenev's landscapes, what changes occur in nature during the day, how the light and tones of color in the description of the sky, air, and trees change.

3. Share your impressions about Turgenev's descriptions of nature. How did your mood change depending on the landscape you read?

4. Look at the painting by Camille Corot, "Morning." Think about what Corot has in common with Turgenev's morning landscape, and what is the difference?

Above, the aesthetic level of Turgenev's perception of nature was considered, but there is also an equally important philosophical level that must be drawn to the attention of senior students. The Russian writer created his own original concept of nature. In his work, starting from the $1850 \mathrm{~s}$, there is an understanding of nature, coming from Schopenhauer, as a blind force that acts "according to general laws, without deviations, without individuality, and the same force of nature is found in exactly the same way in all millions of its manifestations" [33, from. 174]. However, a reflective person cannot and does not want to come to terms with the thought of the indifference of nature, with its defenselessness in front of the finitude of being. Furthermore, in Turgenev's works, a "rebellious" person appears (Elena Stakhova, the protagonist of "On the Eve" novel, in the scene "At the bedside of the dying Insarov," and Bazarov in the second part of the novel "Fathers and Sons"). And only "the nature person," obeying the laws of nature, is devoid of this fear of death. The writer quite definitely speaks about this in his story "Death": "A Russian peasant is dying amazingly! His state before his death cannot be called indifference or stupidity; he dies as if he is performing a ceremony: cold and simple” (11, vol. III, p. 200).

\section{Results and discussion}

1. In the discussion about the study of Turgenev at school, which took place within the framework of the VII St. Petersburg International Cultural Forum, literature teachers expressed the opinion that the reason for the problematic perception of the writer's literary world by modern schoolchildren is associated with their unpreparedness for understanding the manor text, its structure, and figurative system. This opinion was confirmed by our observations and long-term work at school. Turgenev, in his manor genres, and above all in his manor novels "Rudin," "Noble Nest," "On the Eve," "Fathers and Sons," developed a unique form of artistic modeling of the Russian national space [34, p. 61]. Of course, the non-formal sign of the manor topos presence in the writer's works allows us to classify them as manor texts. The main thing is the internal organization, structuring the novels' artistic space, and their unique world concept associated with the idea of paradise, paradise on earth, a special cultural area that was personified by the Russian manor.

The action of the manor text takes place in the cultural space of the manor, which includes the house and its interiors, various architectural buildings, and the garden with its alleys, gazebos, grottoes, pavilions, labyrinths, ponds, streams, and bridges. It also includes all the romantic components of this space: the moon, stars, sky, shadow, sunrise, and sunset. Manor loci can act as "characters" of the story or key motives, concepts of the manor text. 
Learning to read manor novels is always associated with immersion in the cultural environment of the manor, understanding its signs and figurative structure. But it turns out that, as practice shows, schoolchildren approach the study of Turgenev's most complicated novel, "Fathers and Sons," without having any idea of either the manor culture or the world of Turgenev's manor texts. Therefore, a simple way out is suggested: the study of the novel "Fathers and Sons" should be preceded by a lesson devoted to an independent reading of one of the writer's manor novels ("Rudin" or "Noble Nest"), which is in the 10th-grade literature program (edited by G.S. Merkin, S.A. Zinin, V.A. Chalmaev) [35]. Preparing students for this lesson, the literature teacher offers consultations and a system of individual assignments, so the students would be able to speak at a discussion lesson on one of these novels. The majority of students, as a rule, on the recommendation of their teachers or parents, choose the novel "Noble Nest."

Here is an approximate list of these tasks:

1. What impression did Turgenev's novel make on you? What feelings did it evoke in you? What scenes are especially memorable? What were you thinking after you finished reading the novel?

2. How do you imagine the space of the manor recreated in the novel "Noble Nest"? If you were the director of a film, what toposes would you show on the screen?

3. Turgenev's novel consists of biographical sketches and lyric-dramatic scenes. How do they interact? Identify parts in the plot related to the development of a love line, and prepare a dramatic reading of one of them.

4. Researchers call Liza Kalitina “the Turgenev's Girl.” What qualities is she endowed with, and how does she differ from other characters?

5. How did you understand the central conflict of the novel and its ending? Why weren't the main characters happy after all, although it was "so close, so possible..."?

6. Find musical scenes in the novel and think about how they relate to developing the novel's plot and its climax. What kind of music would you choose to convey the feelings of love between Lavretsky and Lisa Kalitina?

7. Prepare a staging of one of the lyrical episodes of the novel.

Concluding the work on the "Noble Nest" novel, the teacher leads students to the idea that a distinctive feature of Turgenev's manor novels is the high concentration of the spiritual life of their main characters, who, far from the bustle of the city, lead ideological disputes and live a tense spiritual life. All of this is achieved since the writer invented a capacious form of the novel, which allowed him to organically combine real-life events and develop feelings with intellectual fights, contemplation, and philosophical reflection. This task is served by:

- construction of the plot, which develops in two parallel levels - event and ontological;

- typification of characters (he correlates his top characters with cultural and historical types);

- the introduction of a new character ("the Turgenev's girl");

- an extraordinary saturation of texts with cultural signs and images, especially from philosophy and arts.

The reader, experiencing and comprehending the central collisions of the novels, should come to think about a wide range of social, aesthetic, philosophical, ideological, and ontological problems of life. Therefore, Turgenev's manor novels cannot be attributed only to one genre: they combine a socio-psychological, ideological, and love story. At the same time, these novels test education level, aesthetic taste, ideological convictions, and, most importantly, test the strength of feelings, the character's personality, and the correspondence of their words to their deeds.

Music plays a unique role in each novel. It accompanies the development of a love story, expresses the aesthetic tastes of the characters, conveys what cannot be described in words in 
their feelings and sentiments. So, for example, through the attitude to music, Turgenev shows the impossibility of a union between Liza Kalitina, the protagonist of the "Noble Nest" novel, and Vladimir Panshin. If Panshin is interested in its outer side, Liza, like Lavretsky, is deeply and sincerely moved by music, touching the innermost strings of the soul. The birth of love in the hearts of characters begins with music, and it conveys the culmination of their feelings and speaks about what cannot be expressed in words.

2. Entering the world of Turgenev is impossible without understanding his concept of love, primarily the feeling of first love. The tenth graders have some reading experience of Turgenev's depiction of love (mainly based on the story "Asya"). In the 10th grade, of course, this feeling is understood deeper and more seriously; therefore, turning to lyrical episodes describing the origin and development of love among Turgenev's characters enhances the reading motivation. The famous teacher from "Kingisepp Gymnasium" L.A. Belyanskaya, often begins her lessons on the study of Turgenev's works in the 10th grade with a dramatic reading and staging of scenes of love declaration from the novels.

Of course, the metaphysics of Turgenev's love is rather complicated. In Turgenev's love conflicts, a person's character, personality as a whole, and his or her spontaneous romantic essence are revealed. And the teacher cannot deliver this to the student without modern philological research. The famous Turgenev researcher V.A. Nedzvetsky distinguishes two main types of love in Turgenev's world: spiritually conscious and spontaneously sensual. He calls the first type "winged love" [36], which lifts lovers to the sky, turning them into poets, musicians, heroes. Turgenev portrays such love in his "The Noble Nest" novel. The second type of love is irrational love, and it is akin to passion and completely takes possession of the characters, breaks their fates, and can even lead to a tragic outcome, especially if it encounters the concept of duty, as in the story "Faust." These two types of love are presented in the works of Turgenev in different versions and modifications.

3. Undoubtedly, the study of the main novel of the writer "Fathers and Sons" at school requires new interpretations and methodological ideas. It is the clearest example of a classic work that has absorbed many of the meaning of its era and, thanks to its rich cultural strata, found life in the "big time." For a long time in school practice, it was read mainly as a socio-psychological novel, in which two generations clash - noble liberals and raznochintsy democrats - in their ideological, moral dispute about the problems of Russian life in the 60s of XIX century. But this is all in the past. It can be read as a novel about the spiritual quest of young people in a modern socio-cultural context, raising the eternal problem of "Fathers and Sons," "physicists and lyricists," and as a philosophical work about the enduring values of life.

These problems were most of all actualized in new television series, stage, and film adaptations based on it. Unfortunately, a modern teacher rarely turns to these adaptations due to the lack of school hours and the lack of methodological skills to use them in the educational process. The difficulty of working with the stage and film adaptations lies in the fact that a literary work undergoes transposition, a peculiar translation from the verbal language into the visual language. Of course, for a conversation about a stage or a film adaptation to occur, it is necessary to be simultaneously in the same semantic field with the novel author, its text, and the director of the adaptation. Consequently, both the literature teacher and the students need at least elementary information about the language of theatrical and movie art and the methodological guidance for their interpretive activity [37, p. 26-29].

Of course, when using visual versions of the text, the literary text should always remain the basis, the matrix for the interpretive students' activity. But life shows that our schoolchildren often judge a writer's literary world only by these adaptations, not by the original texts. And this 
phenomenon is becoming typical: the rendered text is more easily perceived by the multimedia community than the text of fiction, which requires a thoughtful and erudite reader. Therefore, if earlier the educators recommended getting acquainted with the film adaptation after reading and studying the text, now the literature teacher often has to change tactics: the text is read after the screen version has been watched, in the process of perception of which the recipient develops a specific concept of it, and subsequently tries to transfer it to the text. As a result, a literature teacher has to familiarize students with the screen versions of the studied works and their stage adaptations posted online. These adaptations should also be taken into account when preparing for lessons to create an educational dialogue on the issues raised in a literary work and its adaptations.

In recent years, Avdotya Smirnova's TV series "Bazarov's Mistake" has been an original film adaptation of "Fathers and Sons," the introduction of which in the class will undoubtedly help to remove standard approaches to the interpretation of "Fathers and Sons" novel. According to the classification of G.A. Polichko [38], this is a mixed type of film adaptation based on the novel with a relatively complete reproduction of its family scenes.

Most of the film was filmed in Spasskoye-Lutovinovo, where the "old men Bazarovs" house was built in the orchard. The filmmakers succeeded in conveying the manor atmosphere of the novel very well, the details of life, and the furnishings of the noble nests.

Each episode of the TV series was opened with the romance "When the soul is embraced by confusion / And everything breathes with a premonition of love..." created by the series composers. It is performed in two voices by Anna Odintsova and her sister Katya. The romance and flowers that Fenichka sorts out immediately immerse the viewer in the atmosphere of the manor chronotope. But Turgenev's high tragedy initially disappears here. The film adaptation's ideological and philosophical problems are almost not raised; the primary attention is paid to the love in the family, fatherhood, motherhood, moral and psychological conflicts.

The first mise-en-scene of the film evidences that the director is not going to follow the text literally. Nikolai Petrovich meets his son and his friend at the inn not on a warm spring day but in rainy weather: there is dampness, mud, puddles everywhere. However, cheerful young voices contrast with the despondency of nature, and they inspire it. Since the appearance of Arkady and Eugene in the Kirsanov estate, the measured life of the manor has been disrupted. Young people frolic a lot, play, get into new relationships. As in the novel, Bazarov works a lot and retires in his "banya," but he is no stranger to entertainment either. After the characters arrived in the provincial town, Bazarov suddenly became fond of playing thimbles (of course, this scene is not in the novel) and loses several times.

The scriptwriters of the film constantly deliberately disrupt and reshuffle the course of events. Thus, the story of Pavel Petrovich and the Dutches R., Arkady tells Bazarov not in the family estate but on the way to the provincial town, where they go to "unwind."

The famous ideological dispute between fathers and sons in the film adaptation is devoid of its ideological intensity and happens somehow routinely. Bazarov and Arkady drink and eat while talking about politics and art. Pavel Petrovich constantly interferes in their conversation, who nervously walks around the dining room, showing with all his appearance the unacceptability of the position of young people. Bazarov in the television series can be rude, even impudent, but he can also be gallant, even liked by others, appearing at a ball in an elegant frock coat.

It is a pity that the TV series also lacks Mozart's sonata, which Katya performed. Turgenev's appeal to Mozart's work helps to better understand and comprehend the novel's philosophical and aesthetic conflicts [34, p. 228-230]. The famous scene "At the Haystack" is also not in the film, in which Bazarov gives his monologue about the insignificance of man in the face of a vast 
cosmos (Blaise Pascal's idea of a thinking reed). The film also lacks the motive of the knight of Toggenburg, through which the novel illustrates the romantic love of Pavel Petrovich and the development of Bazarov's feelings of love. Nevertheless, in the series, Bazarov's love for Anna Sergeevna Odintsova is convincingly shown, though the scene of the declaration of love itself is unconvincing. The night disappears with its annoying freshness and romance. For some reason, the declaration takes place in the dining room, in the afternoon, among dishes and crystal, which should symbolize the coldness of the heroine's feelings.

The film's undoubted success is the convincing performance of Sergei Yursky and Natalya Tenyakova, playing the roles of the "old men Bazarovs," gentle, humble, and selflessly loving their son. Perhaps the most powerful scenes in the television series are Odintsova's visit to the dying Bazarov, the hope in the parents to save their son, and then the desperate murmur of Vasily Ivanovich, who is experiencing the death of his Evgeny, and daring to threaten God with raised fists.

The final scene of the television series is sad and touching: Pavel Petrovich sets off along a snow-covered road in a sleigh, leaving his family estate after the double wedding of his brother Nikolai Petrovich and nephew Arkady. Furthermore, at the same time, there are the "old men Bazarovs" walking along the path trodden in the snow to their son's grave. The actors raised this scene to high art, conveying the boundless grief of their parents and their all-conquering love.

The inclusion of viewers' interpretations in the structure of a literature lesson while studying "Fathers and Sons" allows an in-depth study of individual episodes in the text, ambiguously comprehending the images of the characters and the author's world concept as a whole. For this purpose, unique techniques are used, which in the Literature teaching methods are called techniques of translating a literary work into works of other arts [39, part 1, p. 172-185]. Let us single out these basic techniques that are found in the practical activities of a modern literature teacher:

1. Compare literary text scenes and their adaptations to identify their role in the works of different arts.

2. Find characteristics of the characters of the two works: appearance, speech, actions, the general interpretation of the character's image.

3. Reveal the essence of the conflict and the features of the literary text and its adaptation.

4. Search for the most obvious ways to identify the position of the author and its adaptation.

5. Compare the film adaptation with the original text to identify life scenes' common and distinctive features.

6. Write reviews on a literary work and a film and posting them online. The reviews can also be heard and discussed during the lesson.

7. Turgenev's novel "Fathers and Sons" has turned out to be so popular in our time so that modern authors create their remakes based on it. Addressing them also contributes to the actualization of Turgenev's text, although it requires the teacher to be very skillful and able to place the necessary accents to see what is the enduring value of a classic work. So, recently on the stage of the Vladimir Mayakovsky Theater, a stage production based on the play by the Irish playwright Brian Friel "Fathers and Sons" was shown (directed by Leonid Kheifets). The performance aroused the interest of a specific audience with its postmodern drama and a number of fascinating stage solutions. The playwright tried to interpret the plot lines of Turgenev's novel in a new way and, proceeding from the original text, created his "Fathers and Sons." But his text turned out to be so much weaker than Turgenev's that at times aroused irritation among the audience, although, according to one of them, with whom the author of the article had a 
conversation, there are many "cool scenes" in it. (episodes from this performance and a short speech by the director can be viewed at https://www.youtube.com/watch? $\mathrm{v}=\mathrm{oAnKfwrDOWg}$ )

Another example is the introduction of Vera Tchaikovskaya's novel "New under the Sun" during a lesson on "Fathers and Sons." Conducting such a lesson dialogue between classics and modernity expands the novel's cultural context, lets us consider some of its issues differently, and intensifies the students' reading activity.

Tchaikovskaya's novel is an independent work about the problems of Russian reality in the early 1990s, but it is built according to the "template" of "Fathers and Sons." Already the title of the story - "New under the sun" and the name of the protagonist - Max (Maximilian) orient us to the familiar Turgenev intergenerational conflict. Even more of these associations with "Fathers and Sons" appear when considering the story's plot. From the capital to the "manor," as Arseny Arsenievich Kositsky ironically called his dacha, two young men arrive. They are greeted with joy, although with some anxiety, by the inhabitants of the "manor." Like Bazarov, the owners of the "manor" settle Maximilian in the "annex" - an unfinished banya. The first meal in the Kositskys" house turns into a clash between "Sons" - Maximilian Kuntsevich and Andrey Kositsky and "Fathers" - the famous art critic Andrey's father, Arseniy Arsenievich, his wife Lydia Aleksandrovna and their distant relative, the artist Lev Moiseevich Pieruv. The dialogues and disputes between "Fathers" and "Sons," although they take place in a new socio-cultural environment, undoubtedly remind us of the disputes of Turgenev's characters. Even in the definition of the younger generation position, the word "nihilists" appears in Tchaikovskaya's story, and Kuntsevich agrees with this definition:

"- Yes, nihilists! - suddenly picked up Kuntsevich. - I am glad that this word has been spoken. It is better than Russophobes. In Russia, everything is repeating itself. Thousand times, all the same thing. And the denial was already there. But our predecessors never reached the end in their denial, not even Chaadaev. And we got there. We deny ourselves. We need to break out of this vicious circle" [19].

The above quote makes it possible to understand that there was something new in the nihilists of another century: this is the denying of man. In other words, the industrial and post-industrial epochs gave birth to the mass man, all individuality disappeared. Therefore, the most hated word for Kuntsevich is "spirituality."

"- The word "spirituality", - he admits, - makes me sick" [40]. Interestingly, while being a famous art critic, he lectures on Russian art in many universities worldwide while denying art and spirituality. He is a cynic, a man of a new mercantile age, and treats his activities like a merchant who sells goods in demand.

The story also contains a number of other parallels with Turgenev's novel: this is Kuntsevich's attitude to women and marriage, the denial of the special Russian soul, etc. Thus, the orientation of Tchaikovskaya in her remake-novel makes it possible to address the problems of the 1990s in an interesting and original way, this transitional period of Russian history and culture, when traditional values collapsed, and gaping voids were opened, that had to be filled with other values.

Below you can see the questions and tasks that were used in our lesson dialogue mentioned above.

1. Read the story "New under the Sun" by Vera Tchaikovskaya and be prepared for an analytical discussion.

2. What works of Russian classics are, in your opinion, a remake of this story?

3. How did you understand the meaning of its title?

4. How are the "eternal problems" of the Russian classics raised and discussed in it? What problems of art and creativity are touched in it? 
5. Compare the characters of the story with the characters of the famous work of Russian classics.

6. What is the novelty and originality of Vera Tchaikovskaya's story?

\section{Conclusion}

Thus, the research showed that the study of Turgenev's personality and his creative work in the modern school of the 2010s has stable traditions, manifested in the content of the educational material, the problem-genre system of constructing literature lessons, organization of students' reading activity, and ways of examining the biography of the writer. At the same time, in the methodological science and during the practical activities of literature teachers, certain stereotypes of the writer's personality and creative work have developed. They are manifested in the lag of pedagogical Turgenev studies behind the scientific, simplified understanding of the Russian writer's world, neglecting contemporary forms of Turgenev's works in modern culture.

It is necessary to look for productive ways and forms of acquaintance with the writer's personality, use new genres of creating a biographical sketch, which would be based on the disclosure of the writer's personality development, and his ideological and creative searches.

Particular attention in this article is paid to Turgenev's concept of nature, its aesthetic and philosophical essence, and new methodological techniques used by the teacher to enhance reading activity. The author offers teaching methods to work with Turgenev's literary landscapes, comparing them to the Barbizon school paintings.

Entering the world of Turgenev is impossible without understanding his concept of love, which has received a scientific explanation in modern research. The use of productive techniques for reading the lyrical parts enhances the reader's motivation significantly.

The great difficulties of modern schoolchildren in the perception of Turgenev's artistic world are primarily due to their unpreparedness for reading the manor text, understanding its structure, and a figurative system. Therefore, it is advisable to include a lesson on the independent reading of one of the manor novels (preferably "Noble Nest") for the 10th-grade literature lessons.

The article also proposes new approaches to the study of Turgenev's "Fathers and Sons," which in the modern socio-cultural context can be read as a novel that raises the eternal problem of the relationship between parents and children, as well as "physicists and lyricists." To actualize the "Fathers and Sons" novel and show its everlasting deep meaning, we propose a method of comparing the novel with Avdotya Smirnova's television series "Bazarov's Mistake".

In conclusion of the article, in order to actualize the perception of Turgenev's novel by students, a model of a lesson dialogue was developed with the involvement of works of modern Literature (Vera Tchaikovskaya's adaptation "New under the Sun").

Acknowledgments. The study was carried out with the financial support of the RFBR grant No. 20-013-00684 "Classics in dialogue with the present: theoretical and methodological aspects of the Russian literature study."

\section{References}

1. Antonovich M.A. Asmodey nashego vremeni [Asmodeus of our time]. Literaturno-kriticheskie stat'i [Literary critical articles]. Moscow - Leningrad, Khudozh. Lit. Publ., 1961. 515 p. (in Russian).

2. Domanskiy V.A. "Ottsy i deti” Turgeneva v russkoy literature: parodiiiremeyki [Turgenev's "Fathers and Sons" in the Russian Literature: parodies and remakes]. K Turgenevu v Baden-Baden: sbornik materialov mezhdunarodnykh nauchnykh konferentsiy (2013-2014) [To Turgenev in Baden-Baden: collection of materials of international scientific conference (2013-2014)]. Moscow, Ekon-Inform Publ., 2016. Pp. 106-115 (in Russian).

3. Klyuev N.A. Serdtse Edinoroga. Stikhotvoreniya i poemy [Unicorn Heart. Verses and poems]. Preface by N.N. Skatov, the introductory article by A.I. Mikhailov; ed., preparation of the text and notes V.P. Garnin. Saint 
Petersburg, Russian Christian Academy of Humanities Publ., 1999. 1072 p. (in Russian).

4. Aykhenval'd Yu.I. Siluety russkikh pisateley. Kn. II [Silhouettes of Russian writers. Prince II]. Ed. L.M. Suris. Moscow; Berlin, Direct Media Publ., 2017. 312 p. (in Russian).

5. Kleman M.K. Ivan Sergeevich Turgenev. Ocherk zhizni i tvorchestva [Ivan Sergeevich Turgenev. Sketch of life and work]. Leningrad, Goslitizdat Publ., 1936. 224 p. (in Russian).

6. Pustovoyt P.G. Ivan Sergeevich Turgenev. Iz kursa lektsiy po istorii russkoy literatury XIX veka [Ivan Sergeevich Turgenev. From the course of lectures on the history of Russian literature of the XIX century]. Ed. A.N. Sokolov. Moscow, Moscow University Publ., 1957. 139 p. (in Russian).

7. Petrov S.M. Turgenev [Turgenev]. Moscow, Uchpedgiz Publ., 1957. 201 p. (in Russian).

8. Efimova E.M. I.S. Turgenev. Seminariy [I.S. Turgenev. Seminary]. Leningrad, Uchpedgiz Publ., 1958. 204 p. (in Russian).

9. Batyuto A.I. Turgenev - romanist [Turgenev - the novelist]. Leningrad, Nauka Publ., 1972. 394 p. (in Russian).

10. Mostovskaya N.N. I.S. Turgenev I russkaya zhurnalistika 70-kh godov XIX veka [I.S. Turgenev and Russian journalism of the 70s of the XIX century]. Leningrad, Nauka Publ., 198. 214 p. (in Russian).

11. Odinokov V.G. Pushkin i Turgenev (Problemy poetiki I tipologii russkogo romana): uchebnoye posobiye dlya studentov [Pushkin and Turgenev (Problems of poetics and typologies of the Russian novel): a manual for students]. Novosibirsk, Nauka Publ., 1968. 128 p. (in Russian).

12. Muratov A.B. Povesti i rasskazy I.S. Turgeneva 1867-1871-kh godov [Novels and short stories by I.S. Turgenev of 1867-1871]. Leningrad, LSU Publ., 1980. 184 p. (in Russian).

13. Shatalov S.E. Khudozhestvennyy mir I.S. Turgeneva [I.S. Turgenev's artistic world]. Moscow, Nauka Publ., 1979. 312 p. (in Russian).

14. Generalova N.P. I.S. Turgenev: Rossiya i Evropa. Iz istorii russko-evropeyskikh literaturnykh i obshchestvennykh otnosheniy [I.S. Turgenev: Russia and Europe. From the history of Russian-European literary and social relations]. Saint Petersburg, Russian Christian Academy of Humanities Publ., 2003. 583 p. (in Russian).

15. Golovko V.M. Khudozhestvenno-filosofskiyeiskaniyapozdnegoTurgeneva (izobrazheniyecheloveka) [Artistic and philosophical quest of the late Turgenev (human image)]. Sverdlovsk, UrSU Publ., 1989. 168 p. (in Russian).

16. Kurlyandskaya G.B. I.S. Turgenev. Mirovozzreniye, metod, traditsii [I.S. Turgenev. Worldview, method, tradition]. Tula, Grifi K Publ., 2001. 229 p. (in Russian).

17. Lebedev Yu.V. Turgenev [Turgenev]. Moscow, Molodaya gvardiya Publ., 1990. (Seriya "Zhizn' zamechatel'nykhlyudey") [(Series "Life of remarkable people")]. 608 p. (in Russian).

18. Markovich V.M. Turgenev irusskiyrealisticheskiy roman XIX veka (30-50-e gody) [Turgenev and the Russian realistic novel of the XIX century (30-50s)]. Leningrad, 1982. 208 p. (in Russian).

19. Nedzvetskiy V.A. Russkiysotsial'no-universal'nyy roman XIX veka: Stanovleniye $i$ zhanrovaya evolyutsiya [Russian social universal novel of the XIX century: Formation and genre evolution]. Moscow, AO Dialog-MSU Publ., 1997. 262 p. (in Russian).

20. Time G.A. Nemetskayaliteraturno-filosofskayamysl' XVIII-XIX vekov v kontekstetvorchestva I.S. Turgeneva (geneticheskiyeitipologicheskiyeaspekty) [German literary and philosophical thought of the 18th - 19th centuries in the context of I.S. Turgenev (genetic and typological aspects)]. Vorträge und AbhandlungenzurSlavistik. Band 31. München, Verlag Otto Sagner Publ., 1997. 144 p. (in Russian).

21. Naumova N.N. Ivan Sergeevich Turgenev: biografiyapisatelya. 2-e izd. [Ivan Sergeevich Turgenev: biography of the writer. 2nd ed.]. Leningrad, Prosveshcheniye Publ., 1976. 160 p. (in Russian).

22. Turgenev $v$ shkole. Posobiyedlyauchiteley [Turgenev at school. Manual for teachers]. Compl. T.F. Kurdyumova. Moscow, Prosveshcheniye Publ., 1981. 192 p. (in Russian).

23. Kurlyandskaya G.B. Turgenev I russkaya literatura: ucheb. posobiye dlya studentov ped. in-tov [Turgenev and Russian literature: textbook for students of pedagogical institutes]. Moscow, Prosveshcheniye Publ., 1980. 192 p. (in Russian).

24. Lebedev Y.V. Ivan Sergeevich Turgenev [Ivan Sergeevich Turgenev]. Moscow, Prosveshcheniye Publ., 1989. 207 p. (in Russian).

25. Drobot V.N. Izucheniye biografii pisatelya $v$ shkole: posobiye dlya uchitelya [Studying the writer's biography at school: teacher's guide]. Kiev, 1988. 189 p. (in Russian).

26. Sukhikh I.N. Literatura: uchebnik dlya 10 klassa [Literature: textbook for grade 10]. In 2 vol. Vol. 2. Moscow, Izd. tsentrAkademiya Publ., 2011. 368 p. (in Russian). 
27. "Tvoy drug i mat' Varvara Turgeneva". Pis'ma V.P. Turgenevoy k I.S. Turgenevu (1838-1844) ["Your friend and mother Barbara Turgeneva". Letters of V.P. Turgeneva to I. S. Turgenev (1838-1844)]. Tula, Grifi K Publ., 2012. 584 p. (in Russian).

28. Literatura. 10 klass: uchebnik. V 2 ch. Ch. 1.6 izd. [Literature. Grade 10: textbook. In 2 parts. Part 1.6 ed.]. Moscow, 2009. 383 p. (in Russian).

29. Lotman Yu.M. Biografiya - zhivoyelitso [Biography - a living face]. Novyy mir, 1985, no. 2, pp. 228-236 (in Russian).

30. Zaytsev B.K. Zizn' Turgeneva, Literaturnaya biografiya [Turgenev's life: A literary biography]. Moscow, DruzhbanarodovPubl., 2000. 224 p. (inRussian).

31. Literatura. 10 klass [Literature. Grade 10]. Ed. B. A. Lanin. Moscow, VENTANA-GRAF Publ., 2018 (in Russian).

32. Turgenev I. S. Polnoye sobraniye sochineniy I pisem: v 30 t. T. 4 [Complete works and letters in thirty volumes. In 30 vol. Vol. 4]. Moscow, Nauka Publ., 1980. 687 p. (in Russian).

33. Shopengauer A. Ponyatiye voli [Notion of will]. Sbornik proizvedeniy. Per. s nem; Vstup. st. I primechaniya I.S. Narskogo [Collection of works. Translation from German; introductory article and notes by I.S. Narsky]. Minsk, Popurri Publ., 1999. 464 p. (in Russian).

34. Domanskiy V.A., Kafanova O.B. Khudozhestvennye miry Ivana Turgeneva [Artistic worlds of Ivan Turgenev]. Moscow, Flinta Publ., 2018. 432 p. (in Russian).

35. Programma po literature dlya 5-11 klassov obshcheobrazovatel'noy shkoly. 6-e izd. [Literature program for 5-11 grades of secondary school. 6 ed.]. Compl. G.S. Merkin, S.A. Zinin, V.A. Chalmaev. Moscow, OOO TID Russkoye slovo - RS Publ., 2010. 200 p. (in Russian).

36. Nedzvetskiy V.A. I.S. Turgenev: logika tvorchestva I mentalitet geroya: kurs lektsiy [I.S. Turgenev: the logic of creativity and the mentality of the hero. Lecture course]. Moscow, Sterlitamak Publ., 2008. 232 p. (in Russian).

37. Domanskiy V.A. Ekranizatsiya kak interpretatsiya literaturnoy klassiki [Screen adaptation as an interpretation of literary classics]. Literatura $v$ shkole, 2018, no. 1, pp. 26-29 (in Russian).

38. Polichko G.A. Osnovy kinematograficheskikh znaniy na urokakh literatury v sredney shkole [Fundamentals of cinematic knowledge in literature classes in high school]. Kurgan, 1980. 147 p. (in Russian).

39. Metodika prepodavaniya literatury: posobiye dlya studentov I prepodavateley: $v 2 \mathrm{ch}$. Ch. 1 [Methods of teaching literature: manual for students and teachers: in 2 vol. Vol. 1]. Ed. O.Yu. Bogdanova and V.G. Marantsman. Moscow, Prosveshcheniye, VLADOS Publ., 1994. 288 p. (in Russian).

40. Chaykovskaya V.I. Novoye pod solntsem [New under the sun]. Novyy mir. 1995, no. 7 URL: http://magazines. russ.ru/novyi_mi/1995/7/chaykov.html (accessed 13 December 2018) (in Russian).

Valery A. Domansky, Doctor of Pedagogical Science, Professor, St. Petersburg Institute of Business and Innovation (Gavanskaya St., 3, St. Petersburg, Russia, 196106).

E-mail: valerii_domanski@mail.ru 